\title{
Effect of children's and parents' smoking on respiratory symptoms
}

\author{
MARTIN BLAND, BEULAH R. BEWLEY, VIRGINIA POLLARD, and MICHAEL H. BANKS
}

From the Department of Community Medicine, St. Thomas's Hospital Medical School, and Department of Clinical Epidemiology and Social Medicine, St. George's Hospital Medical School, London

SUMMARY It has been suggested that the apparent relationship between children's cigarette smoking and their respiratory symptoms could be explained by the effect of parents' smoking upon both child's smoking and symptoms. This was investigated in a study of 6000 Derbyshire schoolchildren. Children who smoked regularly were more likely than nonsmokers to report cough first thing in the morning, cough at other times during the day or at night, and breathlessness. Children whose parents smoked were also more likely to report these symptoms than were the children of nonsmokers. Both the child's and parents' smoking were independently related to the child's respiratory symptoms.

Morning cough was less prevalent than cough at other times during the day or at night, but the relationship between the child's smoking and morning cough was much closer than its relationship to cough at other times. The relationship between parents' smoking and the child's symptoms was similar for each symptom.

Parental cigarette smoking can affect the health of children. An increased incidence of bronchitis and pneumonia in the first year of life has been found among children whose parents smoked when compared to the children of nonsmokers (Colley $\epsilon t$ al., 1974), 5-year-old children of smokers have been reported to have more respiratory symptoms than those of nonsmokers (Norman-Taylor and Dickinson, 1972), and among older children an increased prevalence of day or night cough has been reported among the children of smokers (Cameron et al., 1969; Colley et al., 1974). Colley (1974) also showed that much of this effect of smoking may be accounted for by cross-infection from parents with bronchitis, itself often a consequence of their own smoking. Cigarette smoke in the atmosphere may also be directly harmful, as short-term increases in heart rate and blood pressure have been reported in children exposed to cigarette smoke (Luquette et al., 1970). Cigarette smoking by the children has also been shown to be associated with respiratory symptoms (Holland and Elliott, 1968; Holland et al., 1969; Bewley et al., 1973; Bewley and Bland, 1976), and the prevelance of these symptoms increases with increasing cigarette consumption.

Most studies of children's smoking have found that children who smoke are more likely than nonsmokers to have parents who are smokers (Bothwell 1959; Cartwright and Thomson, 1960; Lemin, 1966;

Received 30 June 1977
O'Rourke and Wilson-Davis, 1970; Bewley et al., 1974; Bewley and Bland, 1976), although this was not found by Bynner (1969) in his major study of secondary school boys. As a result of this, it has been suggested (W. Norman-Taylor, personal communication, 1974), that the apparent relationship between the child's smoking and his respiratory symptoms may be due to both independently being consequences of the parents' smoking, rather than the child's smoking having any direct effect upon respiratory symptoms. In this paper we investigate the relationship between smoking by parents and children, and the child's respiratory symptoms.

\section{Method}

In July 1974 all first-year children in a random sample of 48 secondary schools in Derbyshire were asked to complete a self-administered questionnaire about their smoking and respiratory symptoms (Banks et al., 1978). Questionnaires were obtained from 3098 boys and 3232 girls, $86 \%$ of the children, $2 \%$ having refused and $13 \%$ being absent. Three questions were asked about respiratory symptoms: 'Do you usually cough first thing in the morning?', 'Do you usually cough during the day or at night?', and 'Do you get short of breath when hurrying on flat ground or walking up a slight hill?'. The children were asked about their own cigarette smoking and whether their parents smoked cigarettes. Children who did not 
have both parents living in the home were excluded from this analysis, as were those who did not know whether their parents smoked or who did not reply to the question. 11 children who did not report their own smoking were also excluded, leaving a total of 2847 boys, $92 \%$ of responders, and 2988 girls, also $92 \%$ of responders.

The effect of the child's and parents' smoking on respiratory symptoms was examined using the maximum likelihood method of Dyke and Patterson (1952). This method provides an analysis for proportions analogous to the analysis of variance used when the dependent variable is continuous. The child's smoking and the parents' smoking were regarded as two factors, each with several levels, and the proportion of children reporting the respiratory symptom was the response to these factors, that is, the dependent variable. The logit transformation was used to transform these proportions, and a linear model fitted. The effect of any interaction between the factors upon the transformed proportions was tested. If this interaction was not significant at the $5 \%$ level then the effects of the two factors independently were examined. Each factor was controlled for the effect of the other.

\section{Results}

The prevalence of smoking by children and parents is shown in Table 1. Boys were more likely to smoke than girls, and both were more likely to smoke if their parents did. Because some of the subgroups of child smokers were small, in subsequent tables we have combined children who smoked 1 or more cigarettes a day with those who smoked 1 or more a week, and also those groups where one parent only was a smoker.
Table 2 shows the prevalence of reported cough first thing in the morning and the relationship of this to both the parents' smoking and the child's own smoking. Children who smoked were more likely to report a morning cough than were the children who did not, and the proportion reporting the symptom increased as the amount smoked increased. Children whose parents smoked were more likely to report a morning cough than were the children of nonsmokers, and the proportion of children reporting the symptoms was greatest when both parents smoked. For boys, only the effect of the child's own smoking was significant $(P<0.001)$. The effect of the parents was not significant $(0 \cdot 05<P<0 \cdot 10)$. For the girls there were significant effects of both the child's and parents' smoking; each relationship remained significant when the other was allowed for (parents $\mathbf{P}<0.05$, child $P<0.001$ ). For neither boys nor girls was there any interaction between the effects of parents' and child's smoking on respiratory symptoms, that is, there was no evidence that the effect of parental smoking was different when the child was a nonsmoker from that when the child was a smoker, or that the effect of the child's own smoking was altered by the parents' smoking. The effects of the two factors appeared to be additive.

The prevalence of cough at other times during the day or at night is shown in Table 3. This was more frequently reported than cough first thing in the morning, the overall prevalence of day or night cough being $25 \%$ compared to $4 \%$ for morning cough. Among both boys and girls, smoking by child and by parent were each associated with an increase in the prevalence of the symptom. The patterns for boys and girls were very similar. The effect of the child's smoking was highly significant, even when parents' smoking was taken into account

Table 1 Prevalence of smoking among children and parents for cases where both parents' and child's smoking is known

\begin{tabular}{|c|c|c|c|c|c|c|c|c|c|c|c|c|}
\hline \multirow{3}{*}{ Parents' smoking } & \multicolumn{10}{|c|}{ Child's cigarette smoking } & & \\
\hline & \multicolumn{2}{|c|}{$\begin{array}{l}\text { Never } \\
\text { smoked }\end{array}$} & \multicolumn{2}{|c|}{$\begin{array}{l}\text { Smoked } \\
\text { only once }\end{array}$} & \multicolumn{2}{|c|}{$\begin{array}{l}\text { Smoke } \\
\text { occasionally }\end{array}$} & \multicolumn{2}{|c|}{$\begin{array}{l}\text { Smoke } 1 \text { or more } \\
\text { per week }\end{array}$} & \multicolumn{2}{|c|}{$\begin{array}{l}\text { Smoke } 1 \text { or more } \\
\text { per day }\end{array}$} & \multicolumn{2}{|c|}{ Total } \\
\hline & $n$ & $\%$ & $n$ & $\%$ & $n$ & $\%$ & $n$ & $\%$ & $n$ & $\%$ & $n$ & $\%$ \\
\hline $\begin{array}{l}\text { Boys } \\
\text { Neither } \\
\text { Mother only } \\
\text { Father only } \\
\text { Both }\end{array}$ & $\begin{array}{l}480 \\
140 \\
292 \\
391\end{array}$ & $\begin{array}{l}56 \cdot 6 \\
39 \cdot 9 \\
42 \cdot 9 \\
40 \cdot 4\end{array}$ & $\begin{array}{l}256 \\
150 \\
243 \\
327\end{array}$ & $\begin{array}{l}30 \cdot 2 \\
42 \cdot 7 \\
35 \cdot 7 \\
33 \cdot 8\end{array}$ & $\begin{array}{r}90 \\
43 \\
104 \\
159\end{array}$ & $\begin{array}{l}10 \cdot 6 \\
12 \cdot 3 \\
15 \cdot 3 \\
16 \cdot 4\end{array}$ & $\begin{array}{l}13 \\
10 \\
24 \\
45\end{array}$ & $\begin{array}{l}1 \cdot 5 \\
2 \cdot 8 \\
3 \cdot 5 \\
4 \cdot 6\end{array}$ & $\begin{array}{r}9 \\
8 \\
17 \\
46\end{array}$ & $\begin{array}{l}1 \cdot 1 \\
2 \cdot 3 \\
2 \cdot 5 \\
4 \cdot 8\end{array}$ & $\begin{array}{l}848 \\
351 \\
680 \\
968\end{array}$ & $\begin{array}{l}100.0 \\
100 \cdot 0 \\
100.0 \\
100.0\end{array}$ \\
\hline Total & 1303 & $45 \cdot 8$ & 976 & $34 \cdot 3$ & 396 & $13 \cdot 9$ & 92 & $3 \cdot 2$ & 80 & $2 \cdot 8$ & 2847 & $100 \cdot 0$ \\
\hline $\begin{array}{l}\text { Girls } \\
\text { Neither } \\
\text { Mother only } \\
\text { Father only } \\
\text { Both }\end{array}$ & $\begin{array}{l}673 \\
233 \\
398 \\
498\end{array}$ & $\begin{array}{l}72 \cdot 1 \\
58 \cdot 2 \\
57 \cdot 8 \\
51 \cdot 6\end{array}$ & $\begin{array}{l}213 \\
116 \\
214 \\
304\end{array}$ & $\begin{array}{l}22 \cdot 8 \\
29 \cdot 0 \\
31 \cdot 1 \\
31 \cdot 5\end{array}$ & $\begin{array}{r}37 \\
39 \\
66 \\
123\end{array}$ & $\begin{array}{r}4 \cdot 0 \\
9 \cdot 8 \\
9 \cdot 6 \\
12 \cdot 7\end{array}$ & $\begin{array}{r}7 \\
8 \\
6 \\
33\end{array}$ & $\begin{array}{l}0.7 \\
2.0 \\
0.9 \\
3.4\end{array}$ & $\begin{array}{l}4 \\
4 \\
4 \\
8\end{array}$ & $\begin{array}{l}0.4 \\
1.0 \\
0.6 \\
0.8\end{array}$ & $\begin{array}{l}934 \\
400 \\
688 \\
966\end{array}$ & $\begin{array}{l}100 \cdot 0 \\
100 \cdot 0 \\
100 \cdot 0 \\
100 \cdot 0\end{array}$ \\
\hline Total & 1802 & $60 \cdot 3$ & 847 & $28 \cdot 3$ & 265 & 8.9 & 54 & $1 \cdot 8$ & 20 & 0.7 & 2988 & $100 \cdot 0$ \\
\hline
\end{tabular}


Table 2 Prevalence* of morning cough for different smoking groups

\begin{tabular}{|c|c|c|c|c|c|c|c|c|c|c|}
\hline \multirow{3}{*}{ Parents' smoking } & \multicolumn{8}{|c|}{ Child's cigarette smoking } & \multirow{2}{*}{\multicolumn{2}{|c|}{ Total }} \\
\hline & \multicolumn{2}{|c|}{ Never smoked } & \multicolumn{2}{|c|}{ Smoked only once } & \multicolumn{2}{|c|}{ Smoke occasionally } & \multicolumn{2}{|c|}{$\begin{array}{l}\text { Smoke I or more } \\
\text { per week }\end{array}$} & & \\
\hline & $n$ & $\%$ & $n$ & $\%$ & $n$ & $\%$ & $n$ & $\%$ & $n$ & $\%$ \\
\hline $\begin{array}{l}\text { Boys } \\
\text { Neither } \\
\text { One } \\
\text { Both }\end{array}$ & $\begin{array}{ll}11 & (480) \\
16 & (432) \\
14 & (391)\end{array}$ & $\begin{array}{l}2 \cdot 3 \\
3 \cdot 7 \\
3 \cdot 6\end{array}$ & $\begin{array}{r}6(256) \\
13(393) \\
9(327)\end{array}$ & $\begin{array}{l}2 \cdot 3 \\
3 \cdot 3 \\
2 \cdot 8\end{array}$ & $\begin{array}{l}3 \quad(90) \\
6(147) \\
7(159)\end{array}$ & $\begin{array}{l}3 \cdot 3 \\
4 \cdot 1 \\
4 \cdot 4\end{array}$ & $\begin{aligned} 4 & (22) \\
11 & (59) \\
18 & (91)\end{aligned}$ & $\begin{array}{l}18 \cdot 2 \\
18 \cdot 6 \\
19 \cdot 8\end{array}$ & $\begin{array}{l}24(848) \\
46(1031) \\
48 \quad(968)\end{array}$ & $\begin{array}{l}2 \cdot 8 \\
4 \cdot 5 \\
5 \cdot 0\end{array}$ \\
\hline Total & $41(1303)$ & $3 \cdot 1$ & $28(976)$ & $2 \cdot 9$ & $16(396)$ & $4 \cdot 0$ & $33(172)$ & $19 \cdot 2$ & $118(2847)$ & $4 \cdot 1$ \\
\hline $\begin{array}{l}\text { Girls } \\
\text { Neither } \\
\text { One } \\
\text { Both }\end{array}$ & $\begin{aligned} 6 & (673) \\
14 & (631) \\
12 & (498)\end{aligned}$ & $\begin{array}{l}0.9 \\
2 \cdot 2 \\
2 \cdot 4\end{array}$ & $\begin{array}{r}6(213) \\
13(330) \\
19(304)\end{array}$ & $\begin{array}{l}2 \cdot 8 \\
3 \cdot 9 \\
6 \cdot 3\end{array}$ & $\begin{array}{r}2(37) \\
4(105) \\
10(123)\end{array}$ & $\begin{array}{l}5 \cdot 4 \\
3 \cdot 8 \\
8 \cdot 1\end{array}$ & $\begin{array}{ll}3 & (11) \\
2 & (22) \\
5 & (41)\end{array}$ & $\begin{array}{r}27 \cdot 3 \\
9 \cdot 1 \\
12 \cdot 2\end{array}$ & $\begin{array}{lr}17 & (934) \\
33 & (1088) \\
46 & (966)\end{array}$ & $\begin{array}{l}1 \cdot 8 \\
3 \cdot 0 \\
4 \cdot 8\end{array}$ \\
\hline Total & $32(1802)$ & $1 \cdot 8$ & $38(847)$ & $4 \cdot 5$ & $16(265)$ & $6 \cdot 0$ & $10(74)$ & $13 \cdot 5$ & $96(2988)$ & $3 \cdot 2$ \\
\hline
\end{tabular}

- Total number in the group in parentheses.

Table 3 Prevalence* of cough at other times during the day or at night

\begin{tabular}{|c|c|c|c|c|c|c|c|c|c|c|}
\hline \multirow{3}{*}{ Parents' smoking } & \multicolumn{8}{|c|}{ Child's cigarette smoking } & \multirow{2}{*}{\multicolumn{2}{|c|}{ Total }} \\
\hline & \multicolumn{2}{|c|}{ Never smoked } & \multicolumn{2}{|c|}{ Smoked only once } & \multicolumn{2}{|c|}{ Smoke occasionally } & \multicolumn{2}{|c|}{$\begin{array}{l}\text { Smoke } 1 \text { or more } \\
\text { per week }\end{array}$} & & \\
\hline & $n$ & $\%$ & $n$ & $\%$ & $n$ & $\%$ & $n$ & $\%$ & $n$ & $\%$ \\
\hline $\begin{array}{l}\text { Boys } \\
\text { Neither } \\
\text { One } \\
\text { Both }\end{array}$ & $\begin{array}{ll}93 & (480) \\
75 & (432) \\
98 & (391)\end{array}$ & $\begin{array}{l}19 \\
17 \\
25\end{array}$ & $\begin{array}{r}52(256) \\
117(393) \\
92(327)\end{array}$ & $\begin{array}{l}20 \\
30 \\
28\end{array}$ & $\begin{array}{l}25(90) \\
42(147) \\
67(159)\end{array}$ & $\begin{array}{l}28 \\
29 \\
42\end{array}$ & $\begin{aligned} 8 & (22) \\
27 & (59) \\
45 & (91)\end{aligned}$ & $\begin{array}{l}36 \\
46 \\
49\end{array}$ & $\begin{array}{l}178(848) \\
261(1031) \\
302(968)\end{array}$ & $\begin{array}{l}21 \\
25 \\
31\end{array}$ \\
\hline Total & $266(1303)$ & 20 & $261(976)$ & 27 & $134(396)$ & 34 & $80(172)$ & 47 & 741 (2847) & 26 \\
\hline $\begin{array}{l}\text { Girls } \\
\text { Neither } \\
\text { One } \\
\text { Both }\end{array}$ & $\begin{aligned} 96 & (673) \\
127 & (631) \\
111 & (498)\end{aligned}$ & $\begin{array}{l}14 \\
20 \\
22\end{array}$ & $\begin{array}{r}56(213) \\
91(330) \\
104(304)\end{array}$ & $\begin{array}{l}26 \\
28 \\
34\end{array}$ & $\begin{array}{l}11(37) \\
36(105) \\
47(123)\end{array}$ & $\begin{array}{l}30 \\
34 \\
38\end{array}$ & $\begin{aligned} 5 & (11) \\
10 & (22) \\
20 & (41)\end{aligned}$ & $\begin{array}{l}45 \\
45 \\
49\end{array}$ & $\begin{array}{l}168(934) \\
264(1088) \\
282(966)\end{array}$ & $\begin{array}{l}18 \\
24 \\
29\end{array}$ \\
\hline Total & $334(1802)$ & 19 & $251(847)$ & 30 & $94(265)$ & 35 & 35 (74) & 47 & 714 (2988) & 24 \\
\hline
\end{tabular}

*Total number in the group in parentheses.

$(P<0.001)$, as was the effect of the parents' smoking even when the child's was taken into account $(P<0 \cdot 01)$. There was no interaction between the effects of the two factors.

The prevalence of breathlessness is shown in Table 4. The overall prevalence was slightly lower than for cough during the day or at night, but the relationship with smoking was very similar. For both boys and girls, the effects of the parents' and the child's smoking were significant, and there was no interaction between the two effects.

The relationship between symptom and cigarette smoking was similar for morning cough, day or night cough, and breathlessness. The prevalence of the symptom was higher among children who smoked than among children who did not. The prevalence was also higher among the children of smokers than among the children of nonsmokers.
There was no interaction between these two factors. However, the size of the effect of cigarette smoking on the prevalence of symptoms differed from one symptom to another. The effect of a factor upon a symptom may be measured by the relative risk of reporting a symptom in the group with the greatest amount of smoking compared to the group of nonsmokers. For example, after adjusting for the effects of the boy's own smoking (to the 'never smoked' level), the proportion of boys reporting day or night cough was $18 \%$ among those neither of whose parents smoked and $24 \%$ among those both of whose parents smoked. The relative risk of reporting cough when both parents smoke is then $24 / 18$, that is, 1.4 . We can use this to compare the effects of a factor upon the different symptoms. We cannot, of course, compare the effects of different factors upon the same symptom, as the size of the relative risk depends upon 
Table 4 Prevalence* of breathlessness when hurrying on flat ground or walking up a slight hill, for different smoking groups

\begin{tabular}{|c|c|c|c|c|c|c|c|c|c|c|}
\hline \multirow{3}{*}{ Parents' smoking } & \multicolumn{8}{|c|}{ Child's cigarette smoking } & \multirow{2}{*}{\multicolumn{2}{|c|}{ Total }} \\
\hline & \multicolumn{2}{|c|}{ Never smoked } & \multicolumn{2}{|c|}{ Smoked only once } & \multicolumn{2}{|c|}{ Smoke occasionally } & \multicolumn{2}{|c|}{$\begin{array}{l}\text { Smoke } 1 \text { or more } \\
\text { per week }\end{array}$} & & \\
\hline & $n$ & $\%$ & $n$ & $\%$ & $n$ & $\%$ & $n$ & $\%$ & $n$ & $\%$ \\
\hline $\begin{array}{l}\text { Boys } \\
\text { Neither } \\
\text { One } \\
\text { Both }\end{array}$ & $\begin{array}{ll}47 & (480) \\
51 & (432) \\
56 & (391)\end{array}$ & $\begin{array}{l}10 \\
12 \\
14\end{array}$ & $\begin{array}{l}34(256) \\
51(393) \\
54(327)\end{array}$ & $\begin{array}{l}13 \\
13 \\
17\end{array}$ & $\begin{array}{l}16(90) \\
37(147) \\
34(159)\end{array}$ & $\begin{array}{l}18 \\
25 \\
21\end{array}$ & $\begin{aligned} 6 & (22) \\
17 & (59) \\
37 & (91)\end{aligned}$ & $\begin{array}{l}27 \\
29 \\
41\end{array}$ & $\begin{array}{l}103(848) \\
156(1031) \\
181(968)\end{array}$ & $\begin{array}{l}12 \\
15 \\
19\end{array}$ \\
\hline Total & 154 (1303) & 12 & $139(976)$ & 14 & 87 (396) & 22 & $60(172)$ & 35 & 440 (2847) & 15 \\
\hline $\begin{array}{l}\text { Girls } \\
\text { Neither } \\
\text { One } \\
\text { Both }\end{array}$ & $\begin{aligned} 96 & (673) \\
110 & (631) \\
92 & (498)\end{aligned}$ & $\begin{array}{l}14 \\
17 \\
18\end{array}$ & $\begin{array}{l}43(213) \\
63(330) \\
78(304)\end{array}$ & $\begin{array}{l}20 \\
19 \\
26\end{array}$ & $\begin{array}{r}9(37) \\
30(105) \\
38(123)\end{array}$ & $\begin{array}{l}24 \\
29 \\
31\end{array}$ & $\begin{aligned} 4 & (11) \\
8 & (22) \\
17 & (41)\end{aligned}$ & $\begin{array}{l}36 \\
36 \\
41\end{array}$ & $\begin{array}{l}152(934) \\
211(1088) \\
225(966)\end{array}$ & $\begin{array}{l}16 \\
19 \\
23\end{array}$ \\
\hline Total & $298(1802)$ & 17 & $184(847)$ & 22 & 77 (265) & 29 & 29 (74) & 40 & 588 (2988) & 20 \\
\hline
\end{tabular}

*Total number in the group in parentheses.

Table 5 Relative risk* of reporting different symptoms for children who smoke and for children whose parents smoke

\begin{tabular}{|c|c|c|c|c|c|c|}
\hline & \multicolumn{3}{|c|}{$\begin{array}{l}\text { Relative risk for children who smoke } 1 \text { or more cigarettes } \\
\text { per week, over children who have never smoked }\end{array}$} & \multicolumn{3}{|c|}{$\begin{array}{l}\text { Relative risk of children of parents both of whom smoke, over } \\
\text { children neither of whose parents smoke }\end{array}$} \\
\hline & $\begin{array}{l}\text { Cough first thing } \\
\text { in morning }\end{array}$ & $\begin{array}{l}\text { Cough during day } \\
\text { or at night }\end{array}$ & $\begin{array}{l}\text { Breathless when } \\
\text { hurrying }\end{array}$ & $\begin{array}{l}\text { Cough first thing } \\
\text { in morning }\end{array}$ & $\begin{array}{l}\text { Cough during day } \\
\text { or at night }\end{array}$ & $\begin{array}{l}\text { Breathless when } \\
\text { hurrying }\end{array}$ \\
\hline $\begin{array}{l}\text { Boys } \\
\text { Girls }\end{array}$ & $\begin{array}{l}5.9 \\
6.8\end{array}$ & $\begin{array}{l}2 \cdot 4 \\
2 \cdot 6\end{array}$ & $\begin{array}{l}2 \cdot 9 \\
2 \cdot 3\end{array}$ & $\begin{array}{l}1 \cdot 4 \\
2 \cdot 0\end{array}$ & $\begin{array}{l}1.4 \\
1 \cdot 5\end{array}$ & $\begin{array}{l}1 \cdot 4 \\
1 \cdot 3\end{array}$ \\
\hline
\end{tabular}

*Adjusted for the effect of the other factor to the nonsmoker level.

the smoking categories chosen, the use of more extreme categories producing higher relative risks. Table 5 shows the relative risks for each factor. The risks due to parents' smoking is very similar for each symptom. It may be noted that although the relationship between smoking by the boys' parents upon morning cough was not significant, the relative risk was similar to that for other symptoms. This lack of statistical significance may reflect the much lower prevalence of the symptom rather than a lesser effect. The effects of the child's smoking upon breathlessness and cough during the day or at night were very similar in degree, but the effect of the child's smoking upon cough first thing in the morning was much greater than either.

The three symptoms were not independent. Children who reported one symptom were more likely to report others than those who did not report the symptom. In particular, $70 \%$ of boys and $64 \%$ of girls who reported a cough first thing in the morning reported a cough at other times during the day or at night, compared to $24 \%$ of boys and $23 \%$ of girls who did not report a morning cough. Any comparison of the symptoms must take this into account and the risks of reporting different combinations of symptoms must be examined. The relative risk of children who smoked reporting both cough symptoms was $6 \cdot 4$ for boys and $7 \cdot 0$ for girls. For morning cough only these relative risks were 5.1 and 4.5 and for cough at other times during the day or at night only they were 1.7 and $2 \cdot 0$. Although the reporting of both symptoms showed the greatest response to the child's smoking, morning cough alone was more closely related to smoking than day or night cough alone.

\section{Discussion}

Both their parents' and their own smoking were found to have an effect upon the children's respiratory symptoms. The effects of these two factors were independent and, in particular, the relationship between the child's own smoking and respiratory symptoms could not be accounted for by their parents' smoking. The effect of the child's smoking was most marked for cough first thing in the morning, where a sixfold increase in prevalence was observed as against nonsmokers, compared to a twofold increase for other coughs and breathlessness.

The prevalence of children's smoking in this study is similar to recent studies in children of similar age (Bewley et al., 1973; Bewley and Bland, 1976) as is 
the relationship with respiratory symptoms. The prevalence of smoking among their parents corresponds well with the national estimates of Lee (1976), who found $54 \%$ male and $49 \%$ female cigarette smokers in the age group from which most parents of 12-year-old children are likely to come. The relative risk of morning cough among child smokers was also higher than the risk of cough during the day or at night in several other studies (Holland et al., 1969; Bewley et al., 1973; Bewley and Bland, 1976), although to a lesser degree than here. This was not apparent, however, in the data of Holland and Elliott (1968). None of these authors commented on the difference.

A possible objection to our analysis is that the information on smoking and respiratory symptoms was collected from the children themselves. It may be that children expect coughing to be a result of smoking, and this may influence their replies to the questionnaire. However, when data on the child's respiratory symptoms were obtained from the parent, a relationship with parental smoking was still found (Cameron et al., 1969; Norman-Taylor and Dickinson, 1972; Colley, 1974).

Our findings, using symptoms obtained from the child, confirm these reports. An association between the child's symptoms as reported by parents and the child's smoking has also been reported (Holland et al., 1969). A further objection is that other factors, such as area of residence, overcrowding in the home, etc., may account for some or all of the relationships found. The relationship between the child's smoking and respiratory symptoms has been shown to exist for urban and rural dwellers and when social class is taken into account (Holland et al., 1969). Little evidence has been presented on the effect of such factors on the association with parental smoking.

It is difficult to explain the different relationships to smoking of cough first thing in the morning and cough at other times during the day or at night. Both these reported symptoms possibly include a range of both real and imagined respiratory conditions, but it may be that 'cough during the day or at night' includes a number of allergic and other conditions unconnected with tobacco smoke, whereas 'cough first thing in the morning' is a far more specific response to smoking, and may represent the beginnings of a smoker's career of chronic bronchitis. In this study the children will be followed prospectively up to the age of 16 , and it will be interesting to see whether these symptoms continue.

We thank the pupils and staff of the schools who participated in the study, and present and past members of the Derbyshire Health and Education Departments, particularly Dr P. Sylvester, Mr J.
Morris, Dr J. R. Dean, Mrs B. Baggett, and Mr J. Noyce. We acknowledge the help and support of Professor W. W. Holland and Dr A. H. Snaith; and Miss J. Bates for typing. This study was supported in part by the Medical Research Council and in part by the Department of Health and Social Security.

\section{References}

Banks, M. H., Bewley, B. R., Bland, J. M., Dean, J. R., and Pollard, V. M. (1978). Long-term study of smoking by secondary schoolchildren. Archives of Disease in Childhood, $53,12-19$.

Bewley, B. R., and Bland, J. M. (1976). Smoking and respiratory symptoms in two groups of school children. Preventive Medicine, 5, 63-69.

Bewley, B. R., and Bland, J. M. (1977). Academic performance and social factors related to cigarette smoking by school children. British Journal of Preventive and Social Medicine, 31, 18-24.

Bewley, B. R., Halil, T., and Snaith, A. (1973). Smoking by primary school children. Prevalence and associated respiratory symptoms. British Journal of Preventive and Social Medicine, 27, 150-153.

Bewley, B. R., Bland, J. M., and Harris, R. (1974). Factors associated with the starting of cigarette smoking by primary school children. British Journal of Preventive and Social Medicine, 28, 37-44.

Bothwell, P. W. (1959). The epidemiology of cigarette smoking in rural school children. Medical Officer, 102, 125-132.

Bynner, J. M. (1969). The Young Smoker. Government Social Survey. HMSO, London.

Cameron, R., Kostin, J. S., Zaks, J. M., Wolfe, J. H., Tighe, G., Oselett, B., Stocker, R., and Winton, J. (1969). The health of smokers' and non-smokers' children. Journal of Allergy, 43, 336-341.

Cartwright, A., and Thomson, J. G. (1960). Young smokers: an attitude study among school children touching also on parental influence. British Journal of Preventive and Social Medicine, 14, 28-34.

Colley, J. R. T. (1974). Respiratory symptoms in children and parental smoking and phlegm production. British Medical Journal, 2, 201-204.

Colley, J. R. T., Holland, W. W., and Corkhill, R. T. (1974), Influence of passive smoking and parental phlegm on pneumonia and bronchitis in early childhood. Lancet, 2, 1031-1034.

Dyke, V. G., and Patterson, H. D. (1952). Analysis of factorial arrangements when data are proportions. Biometrics, 8, 1-12.

Holland, W. W., and Elliott, A. (1968). Cigarette smoking, respiratory symptoms and anti-smoking propaganda. Lancet, 1, 41-43.

Holland, W. W., Halil, T., Bennett, A. E., and Elliott, A. (1969). Indications for measures to be taken in childhood to prevent chronic respiratory disease. Millbank Memorial Fund Quarterly, 47, 215-227.

Lee, P. N. (1976). Statistics of Smoking in the United Kingdom. 7 th ed. Tobacco Research Council, London.

Lemin, B. (1966). Smoking in 14 year old school children. International Journal of Nursing Studies, 4, 301-307.

Luquette, A. J., Landiss, C. W., and Merki, D. J. (1970). Some immediate effects of a smoking environment on children of elementary school age. Journal of School Health, 40, 533-536. 
Norman-Taylor, W., and Dickinson, V. A. (1972). Dangers for children in smoking families. Community Medicine, 128, 32-33.

O'Rourke, A., and Wilson-Davis, K. (1970). Smoking and school children. Journal of the Royal College of General Practitioners, 20, 354-360.
Correspondence to Dr M. Bland, Department of Community Medicine, St Thomas's Hospital Medical School, London SE1. 